\author{
articles CAN NEWS SITES \\ STIMULATE ONLINE \\ DELIBERATION? \\ a study of readers' comments posted on \\ folha.com \\ Copyright (C) 2012 \\ SBPjor / Brazilian \\ Association \\ of Journalism \\ Researchers \\ RAFAEL CARDOSO SAMPAIO \\ Universidade Federal da Bahia \\ SAMUEL ANDERSON ROCHA BARROS \\ Universidade Federal da Bahia
}

\begin{abstract}
This paper assesses online deliberation on readers' comments on the website of the Brazilian newspaper Folha de S. Paulo. To this end, 260 posts on four different stories were analyzed. In addition to the comments, the newspaper's website, its discursive tools and the political stance of the participants, were examined. It was concluded that there was relevant deliberativeness in discussions but also excessive aggressiveness among participants. The comments posted revealed that most of the participants sought to win debates rather than promoting mutual understanding. Lastly, the paper discusses how to deal normatively with this aggressiveness and attempts to identify ways to increase democratic values through the provision of discursive tools by news sites.

Key-Words: online deliberation; online journalism; participatory journalism; deliberative democracy
\end{abstract}

\title{
OS SITES DE NOTÍCIAS PODEM ESTIMULAR A DELIBERAÇÃO ONLINE? um estudo dos comentários de leitores postados no folha.com
}

RESUMO - Este artigo avalia a deliberação em comentários de leitores no website do jornal Folha de S. Paulo. Para tanto, foram analisados 260 posts relacionados a quatro notícias. Além dos comentários, foram analisados o site do jornal, as ferramentas discursivas e o posicionamento político dos participantes. Concluiu-se que houve um considerável nível de deliberatividade nas discussões analisadas, mas também ocorreu excessiva agressividade entre os participantes. Com relação aos comentários postados, pode-se afirmar que a maioria dos participantes buscou a vitória no debate em vez da compreensão mútua. No final, o artigo considera como lidar normativamente com essa agressividade e tenta mostrar como há certo potencial para aumentar os valores democráticos por meio do fornecimento de ferramentas discursivas por sites de notícias.

Palavras-chave: deliberação online; jornalismo online; jornalismo participativo; democracia deliberativa.

\section{¿LOS SITIOS DE NOTICIAS PUEDEN ESTIMULAR LA DELIBERACIÓN EN LÍNEA? Un estudio de los comentários de los lectores publicados en Folha.com}

Resumen: Este artículo evalúa los comentarios de los lectores de la página web del diario Folha de S. Paulo. Para ello, se analizaron 260 comentarios relacionados con cuatro noticias. Además de las observaciones, se analizaron el sitio electrónico del periódico, sus herramientas discursivas y el posicionamiento político de los participantes. Se concluyó que había un considerable nive de deliberatividad en las discusiones examinadas, pero también una excesiva agresividad entre los participantes. Con respecto a los comentarios publicados, se puede afirmar que la mayor parte de los participantes buscaba la victoria en el debate en lugar de la comprensión mutua. Por último, el artículo considera cómo hacer frente normativamente a esta agresividad e intenta mostrar que existe cierto potencial para mejorar los valores democráticos proporcionando herramientas discursivas en los sitios webs de noticias.

Palabras-clave: deliberación en línea; periodismo en línea; periodismo participativo; democracia deliberativa 


\section{INTRODUCTION}

Throughout the world, there seems to be a consensus that online newspapers should offer readers the option to comment on content. This is certainly the case in Brazil, where big and small newspapers have comments sections. Although the phenomenon emerged in the $21^{\text {st }}$ century, there are already a considerable number of empirical and theoretical studies on it. However, particularly in Brazil, research focuses on the implications of the phenomenon for the field of journalism and the experience of news consumption. Few studies have considered the social and democratic effects of these experiences. In light of this deficiency, this study aims to evaluate possible democratic gains from the use of comments sections.

Readers' comments were analyzed based on normative principles identified by Habermas for a deliberative process ( $\mathrm{NOCl}$ et al., 2010). Criteria and analysis from the field of online deliberation were also applied (DAHLBERG, 2004; GRAHAM, 2008; JANSSEN; KIES, 2005; JENSEN, 2003 KIES, 2010). This article presents data from research completed between 2009.2 and 2010.1, which had partial results already published (SAMPAIO; BARROS, 2010).

\section{THEORETICAL FRAMEWORK Studies on the readers' comments}

The literature on comments from readers arrives at two different conclusions: a) comments pluralize the discourse of newspapers and enrich the experience of online news consumption; b) comments tools function as a loyalty strategy for newspapers and do not promote democratic values or decrease the distance between journalists and readers (PALACIOS, 2010; NOCI et. al., 2010; ROBINSON, 2010; NEWMAN, 2009; FIDALGO, 2004).

The first studies, which had an optimistic perspective, demonstrate an understanding that the opportunity to comment on news brings some benefits, since it offers alternative discourses and allows the expression of views and perspectives that are absent in journalistic content. This participation of readers can ultimately result in the distribution of power to construct narratives (FIDALGO, 2004; FLEW, WILSON, 2010; GILLMOR, 2004).

Regarding social implications, these spaces for expression and interaction between ordinary citizens appear to bring benefits. They 
could enable the broadening of the range of arguments presented by the news story. Fidalgo (2004) explains that the comments sections may be identified as important elements, since they are able to produce a higher semantic density or an additional layer of information and different views. Thus, the news would be a catalyst for discussions about the facts (GOMES; ANDRADE, 2010). In other words, this discursive environment could help foster increased pluralism (NEWMAN, 2009).

However, other authors have argued that newspapers open spaces primarily in order to generate a sense of loyalty among customers (NOCl et. al., 2010; PALACIOS, 2010, ROBINSON, 2010). Offering these tools does not cause structural changes in the making or consumption of journalism. According to Palacios (2010), openness initiatives from traditional newspapers only meet the demands of users who are increasingly connected to cyberspace and, generally, are devised simply to attract readers.

Noci et al. (2010) analyzed 36,059 comments relating to 1,754 news stories from seven Catalonian newspapers (La Vanguardia, El Periódico, Avui, El Punt, Segre, Diari de Tarragona and Diari de Girona) and concluded that comments are the most popular form of audience participation on newspaper websites, as they represent a simpler way for citizens to discuss and react to the events.

Drawing on Habermas's concept of discourse ethics, Noci et al. concluded that the comments hardly meet any of the Habermasian criteria because they lack mutual respect for one another, while the arguments proposed are generally simplistic. In addition, most users posted only one comment. "The majority of the comments are not abusive but they are not fruitful contributions to a rational debate" (ibid., p. 18).

Mitchelstein \& Boczkowski (2010) explain that, in general, the literature on online news production from 2000 to 2010 indicates that expectations regarding the internet's discursive potential were not realized. There are several causes for this frustration, ranging from inequality in access to a lack of motivation to participate. Nevertheless, according to Noci et al. (2010), newspapers also apply legal limits on opportunities to participate, as they are legally responsible for the content posted and readers often post comments that can result in legal sanctions. A common precaution is the prior establishment of standards consistent with democratic principles. Thus, newspapers can take punitive measures without major complications but newspapers typically have few or no employees dedicated to monitoring and moderating comments. 


\section{Public Deliberation, Meta-Consensus}

For Habermas (1996), a major problem with liberal representative democracies is the lack of legitimacy of power. Citizens do not feel well-represented by politicians and their decisions are not considered legitimate since they seem detached from the desires and needs of the civil sphere.

However, this quest for mutual understanding has been taken to represent a constant search for consensus. In this sense, Habermas is criticized for suggesting normative ideals that would be overly demanding and disconnected from the reality of real power struggles (MOUFFE, 2000; SANDERS, 1997; SHAPIRO, 1999). As such, many theorists of deliberative democracy define similar principles to those of the German philosopher but seek to address the goals of deliberation with less stringent foundations. The concept of meta-consensus is particularly highlighted in this approach. In synthesis, "normative meta-consensus implies reciprocal understanding and recognition of the legitimacy of the values held by other participants in political interaction" (DRYZEK; NIEMEYER, 2006, p. 642). That is to say, reaching meta-consensus should be less dependent on the participants' motivations in pursuing the agreement. Even in disagreements that can only be resolved by voting, meta-consensus could help to bring about better results.

According to the authors, meta-consensus promotes the ability of different groups to coexist in a pluralistic society in a civil manner and recognize the common state of belonging in a democratic, political society. As such, the agreement represents a course of action that participants can accept even when it does not reflect their initial preferences. In this case, participants realize that these results are more desirable than those that would appear in the absence of any agreement. This agreement receives approval from the involved citizen because they acknowledge that their needs are recognized and considered (DRYZEK; NIEMEYER, 2006, p. 642-643).

\section{Online Deliberation}

Three main research goals can be identified with respect to this field, which can be classified as online deliberation. The first set of researchers compare face-to-face deliberations with computer-aided or online deliberations, in an attempt to confirm that one can provide the same benefits as the other (HAMLETT, 2002; MIN, 2007). In general, 
the second group of researchers examines deliberations in deliberativeparticipatory programs or deliberative forums hosted by formal political institutions. (DAHLBERG, 2004; GRAHAM, 2008; JENSEN, 2003; MIOLA, 2009).

The latter group analyzes online deliberation "in the wild" by examining online forums, commenting tools and dialogic environments that do not impose strict dialogical rules or provide incentives for deliberation. This field seeks to analyze the quality of discussions that arise naturally among interested citizens. (DANTAS, SAMPAIO, 2010; DAVIS, 2005; JANSSEN, KIES, 2005; KELLY et al, 2009; PAPACHARISSI, 2004; SAMPAIO, MAIA, MARQUES 2011 ; WILHELM, 2000).

In light of the above, this study's approach is delineated by a third perspective, adopting Dahlberg's (2004) stance, which argues that one can achieve more significant results if the goal is to measure the deliberativeness of online discussions and the causes and consequences of these results. In this context, the goal is to select cases that differ from others, so that significant lessons can be learned. This approach may identify problems, constraints, opportunities and successes encountered when these tools are applied, as well as the characteristics that are crucial to their success. Thus, it could demonstrate how an exemplary model could be put into practice (Ibid, 2002, p. 11).

For this reason, the study focuses analysis on the tool that allows users to post comments on Folha.com, a Brazilian online newspaper. Folha.com is generally regarded as an unconducive environment for online deliberation. There are several studies on the democratic and discursive potentialities of comment-posting tools, as well as other digital instruments offered by online newspapers, geared towards reader participation (FIDALGO, 2004; HERMIDA, THURMAN, 2007; KOHN, NEIGER, 2006; ROSENBERRY, 2005). Nonetheless, it would appear that this discursive arena has still not captured the attention of the online deliberation field (with the exception of Manosevitch \& Walker, 2009).

\section{METHODOLOGY}

According to Janssen \& Kies (2005), when evaluating an online discussion, it is necessary to examine the "externalities" that may impact the deliberative process. As such, two structural analyses are suggested by the authors when studying the online forum in question.

The first assesses the political culture and ideology of the participants. Janssen \& Kies (2005) envision an analysis that considers 
the context of the discussion. In this way, it is important to assess: the theme of the debate (1) because it is the main determinant of the direction of the discussion and viewpoints; the political actor hosting the deliberation (2), since this element tends to shape the participants and their positions (participants on the Folha.com forum tend to be the newspaper's readers); and finally, the ideology of the participants (3), because it impacts on their positions and arguments in the deliberation.

In the second, the communicative structure aims to carry out an overall assessment of the forum by first evaluating its "identification" requirements (1), the need for users to identify their names (or lack thereof). The approach also evaluates the "openness and freedom" (2) of the forum. In this context, one can assess whether the forum is moderated or not (and how moderation is carried out), if there are scheduling issues or limitations on participation in the discussion (for example, exclusivity for subscribers). Furthermore, the assessment estimates whether the area of discussion is "strong" or "weak" (3), if the messages are read and considered by the actor hosting the debate. Finally, the site's design is analyzed (4), since the design of digital discussion tools may have a direct impact on the deliberation (WILHELM, 2000).

Table 1: Structural analysis of the forum

\begin{tabular}{|l|l|}
\hline \multicolumn{2}{|l|}{ Online discussion space Structural Analysis } \\
\hline POLITICALCULTURE AND IDEOLOGY & COMUNICATIVE STRUCTURE \\
\hline $\begin{array}{l}\text { P. Topic of Debate } \\
\text { 1. Identification }\end{array}$ \\
\hline $\begin{array}{l}\text { II. The political actors hosting } \\
\text { the online debates }\end{array}$ & 2. Openness and freedom \\
\hline III. Ideology of participants & 3. Weak or Strong public space \\
\hline-- & 4. Design \\
\hline
\end{tabular}

Source: Authors

\section{Discursive Analysis}

In this study, the suggested analytical indicators evaluate if there was dialogue, reflexivity, justification and respect - some of the key criteria identified by Dahlberg (2004) as essential to online deliberation. To this end, 64 posts were selected for the first topic ("Arruda Imprisoned"), 66 for the second ("Brazil-Iran Agreement"), 65 for the third ("Human Rights Plan") and 65 for the fourth ("Political Coup Against Zelaya"). Each theme was analyzed independently. 


\section{a) Dialogue}

Here, the evaluation focuses only on whether the message is replying to a previous post left by another participant (DAHLBERG, 2004), or concerning a topic under discussion, classed as (a) "dialogue." Messages that have no answers but only isolated comments are considered (b) "monological" (JENSEN, 2003; MIOLA, 2009).

\section{b) Reflexivity}

Reflexivity occurs when the participant goes beyond replying to a message within a discussion and begins to re-assess his or her values, thoughts and interests in relation to those conveyed by other participants (DAHLBERG, 2004; JANSSEN, KIES, 2005).

Attention is directed towards investigating whether participants offer new arguments while seeking "progress" (c) of the discussion, or if they change their original views and begin to agree with previously posted opinions. This is termed "persuasion" (d) as suggested by Jensen (2003).

\section{c) Justification}

The presentation of rational arguments is the basis of Habermas's argumentation theory (1996). The process of convincing must be generated by the force of the arguments and as such, the participants should seek to justify them. However, some authors argue that other forms of communication should also be considered in argumentation. In this way, "testimonials" are seen as an important way of justifying the argument (YOUNG, 1996).

Thus, two main forms of justification are considered. On one hand, "external justification" (e) occurs when the reader presents facts, data, links, references, events and newspapers, etc., to justify their arguments to convince other users. On the other hand, "internal justification" involves storytelling and personal accounts (JENSEN, 2003).

\section{d) Respect}

Finally, mutual respect among users fosters the creation of rational arguments and reflection on the arguments of other participants, as well as facilitating the search for a common understanding. However, Papacharissi (2004) shows that not all forms of rough communication inhibit deliberation. Debates can become inflamed 
and generate disagreement but still represent progress. Therefore, the study examines messages with a respectful tone $(\mathrm{g})$, ie, those that demonstrate respect for other participants or groups. Respect can be identified in the form of praise and, in general, it is used to defend the values and rights of these individuals. Posts are considered to have an "aggressive" tone (h) if they contain insults, aggressive ironies, hate, prejudice, etc.

\section{e) Identification}

Each user was classed as a "pseudonym" (i) or "identified" (j) to assess whether there was any direct relationship between lack of identification and aggression.

\section{ANALYSIS AND RESULTS Political Culture and Ideology Debate Theme}

The present study focuses on comments posted by Folha.com readers regarding four main stories. The first ${ }^{1}$, published on February 11 , 2010, discusses the surrender of Federal District Governor, Jose Roberto Arruda, to the authorities, after the Federal Police (FP) issued an arrest warrant, ordered by the Federal Superior Court (FSC), due to allegations that he attempted to bribe a journalist who had information about a corruption scheme within the Federal District's (DF) administration, a case which is currently under federal investigation.

The second article ${ }^{2}$, published on May $18^{\text {th }}$ of 2010 , was about Brazil's diplomatic mediation role, together with Turkey, in settling the crisis between Iran and the International Atomic Energy Agency (IAEA), followed by the rejection of the agreement by the international community and the discussion of sanctions by the UN Security Council.

The third theme concerns the Human Rights Plan decreed by President Luis Inácio Lula da Silva on December 21, 2009. This caused controversy among government ministers, civil society organizations and intellectuals. The theme comprised two main points of contention: 1) the clash between agrobusiness and family-based agriculture and; 2) the proposed investigation of crimes committed by the military during the dictatorship (between 1964 and 1985).

The fourth theme is about the deposition and expulsion of Honduran President Manuel Zelaya, through a military coup, with support from the Supreme Court and Congress, on June 28, 2009. Coup leaders 
accused the president of plotting to create a law that could provide reelection, which is prohibited under the constitutional laws of that country.

\section{THE HOSTS OF THE DEBATE}

Folha.com is the online extension of the Brazilian traditional, printed newspaper Folha de S. Paulo. Participating in journalism entails adopting guidelines, standards and procedures (habitus) for implementing activities in the field, as outlined in Bourdieu's dynamic field theory (BARROS FILHO; MARTINO, 2003). But it is also important to recognize that Folha is an institution that retains its own interests. There exists a fine balance where, on one hand, professionals must abide by certain principles governing journalistic activity to maintain credibility and legitimacy with the public and, on the other hand, political, social and economic pressures that influence the media coverage agenda (MIGUEL; BIROLLI, 2010).

\section{Political Culture}

The objective is to understand the positioning of the messages in relation to the topics under discussion. Comments that were favorable to Lula or Dilma Rousseff (the Workers Party's presidential candidate), the Workers Party (PT) or allies of the government were classed as "situation" (i). Posts that criticized government officials, government actions or supported the opposition, especially Serra (presidential candidate for the Brazilian Social Democratic Party - PSDB), the PSDB, the Democratic Party or opponents of the Lula government, were classed as "opposition" (j).

\section{Communicative Structure Identification}

Although registration is required, identification of the participants was not necessary. The user's login does not require the use of personal names. As Table 2 shows, although identification was not compulsory, the identification rate was high. This observation seems to indicate an important level of commitment to the debate (JANSSEN, KIES, 2005; WRIGHT, STREET, 2007). It was also noted that one cannot correlate the use of pseudonyms with rude messages or few arguments. 


\section{Openness and freedom}

In order to post a comment on "Folha.com", it is necessary to fill out an online registration form with personal data (email, name, date of birth, personal id [CPF], sex, country and zip code). However, according to our analysis, there are no restrictions for the comments tool. The site's moderation occurs after the message is posted. Some swear words are preemptively blocked. However, at any time, users can click on the "report" button that follows each comment and send arguments to moderators to contest censorship.

\section{Public Space}

The set of messages that was assessed did not reveal any evidence of participation from public authorities or even Folha's journalists. Also, there was no indication that the comments were read or viewed by journalists to subsidize news creation or even manage the content of the site. Apparently, there is a team that just reads the comments in order to moderate the messages that are deemed too aggressive. Following Janssen \& Kies' (2005) assessment, the discursive tool offered by Folha.com can be classed as a weak public space with little impact.

\section{Design}

After news items posted on the site, the comments section allows readers to express their opinions. The design gives the reader the opportunity to respond directly to items or another comment. Posts appear in reverse chronological order. Immediately below the item, an option allows the reader to view all comments but only three messages receiving with the highest positive and negative average rating from other users, are highlighted. There is also the option of sending messages on Twitter and Facebook via a link for comments.

The design is simple and functional, while the possibility of responding to another comment encourages dialogue. However, other discursive tools that facilitate discussion are absent, such as the search engine, "emoticons", multimedia resources (videos, sounds, images), or the option to quote other posts or group comments in the reply. This indicates that it is still a simple tool for discussion, and falls short of using options that are readily available on the internet. 


\section{Discurse Analysis}

The table below synthesizes the analysis of the discourse according to the analytical indicators based on some of the criteria defined by Dahlberg (2004) as fundamental for online deliberation. The inter-coder reliability rating was nearly $95 \%$, the disagreements $(\mathrm{N}=12)$ were resolved through discussion between the two coders.

Table 2: Discursive Analysis Results

\begin{tabular}{|c|c|c|c|c|c|c|}
\hline & & $\begin{array}{l}\text { Theme } \\
1 \\
U=64\end{array}$ & $\begin{array}{l}\text { Theme } \\
2 \\
U=66\end{array}$ & $\begin{array}{l}\text { Theme } \\
3 \\
U=65\end{array}$ & $\begin{array}{l}\text { Theme } \\
4 \\
U=65\end{array}$ & $\begin{array}{l}\text { Total } \\
U=260\end{array}$ \\
\hline \multirow[t]{2}{*}{ Tdentification } & Tdentified & $\begin{array}{l}51 \\
(79,7 \%)\end{array}$ & $\begin{array}{l}60 \\
(90,9 \%)\end{array}$ & $\begin{array}{l}57 \\
(87,7 \%)\end{array}$ & $\begin{array}{l}42 \\
(64,6 \%)\end{array}$ & $\begin{array}{l}210 \\
(80,8 \%)\end{array}$ \\
\hline & Pseudonym & $\begin{array}{l}13 \\
(20,3 \%)\end{array}$ & $\begin{array}{l}6 \\
(9,1 \%)\end{array}$ & $\begin{array}{l}8 \\
(12,3 \%)\end{array}$ & $\begin{array}{l}23 \\
(35,4 \%)\end{array}$ & $\begin{array}{l}50 \\
(19,2 \%)\end{array}$ \\
\hline \multirow[t]{2}{*}{ Reciprocity } & Dialogue & $\begin{array}{l}43 \\
(67,2 \%)\end{array}$ & $\begin{array}{l}53 \\
(80,3 \%)\end{array}$ & $\begin{array}{l}48 \\
(73,8 \%)\end{array}$ & $\begin{array}{l}54 \\
(83,1 \%)\end{array}$ & $\begin{array}{l}198 \\
(76,2 \%)\end{array}$ \\
\hline & Monological & $\begin{array}{l}21 \\
(32,8 \%)\end{array}$ & $\begin{array}{l}13 \\
(19,7 \%)\end{array}$ & $\begin{array}{l}17 \\
(26,2 \%)\end{array}$ & $\begin{array}{l}11 \\
(16,9 \%)\end{array}$ & $\begin{array}{l}62 \\
(23,8 \%)\end{array}$ \\
\hline \multirow[t]{2}{*}{ Reflexivity } & Progress & $\begin{array}{l}30 \\
(46,9 \%)\end{array}$ & $\begin{array}{l}33( \\
50 \%)\end{array}$ & $\begin{array}{l}24 \\
(36,9 \%)\end{array}$ & $\begin{array}{l}25 \\
(38,5 \%)\end{array}$ & $\begin{array}{l}112 \\
(43,1 \%)\end{array}$ \\
\hline & Persuasion & $\begin{array}{l}4 \\
(6,3 \%)\end{array}$ & $\begin{array}{l}7 \\
(10,6 \%)\end{array}$ & $\begin{array}{l}4 \\
(6,2 \%)\end{array}$ & $\begin{array}{l}2 \\
(3,1 \%)\end{array}$ & $\begin{array}{l}17 \\
(6,5 \%)\end{array}$ \\
\hline \multirow[t]{2}{*}{ Justification } & External & $\begin{array}{l}21 \\
(32,8 \%)\end{array}$ & $\begin{array}{l}20 \\
(30,3 \%)\end{array}$ & $\begin{array}{l}31 \\
(47,7 \%)\end{array}$ & $\begin{array}{l}31 \\
(47,7 \%)\end{array}$ & $\begin{array}{l}103 \\
(39,6 \%)\end{array}$ \\
\hline & Internal & -- & $\begin{array}{l}5 \\
(7,6 \%)\end{array}$ & $3(4,6 \%)$ & $\begin{array}{l}4 \\
(6,2 \%)\end{array}$ & $12(4,6 \%)$ \\
\hline \multirow[t]{2}{*}{ Tone } & Aggressive & $\begin{array}{l}28 \\
(43,8 \%)\end{array}$ & $\begin{array}{l}45 \\
(68,2 \%)\end{array}$ & $\begin{array}{l}33 \\
(50,8 \%)\end{array}$ & $\begin{array}{l}25 \\
(38,5 \%)\end{array}$ & $\begin{array}{l}131 \\
(50,4 \%)\end{array}$ \\
\hline & Respectful & $\begin{array}{l}10 \\
(15,6 \%)\end{array}$ & $\begin{array}{l}18 \\
(27,3 \%)\end{array}$ & $\begin{array}{l}13 \\
(20 \%)\end{array}$ & $\begin{array}{l}13 \\
(20 \%)\end{array}$ & $\begin{array}{l}54 \\
(20,8 \%)\end{array}$ \\
\hline
\end{tabular}

Source: Authors

The levels of dialogue between participants were surprising, exceeding $70 \%$, given that the analysis looked at a digital tool for posting comments ${ }^{3}$. The fact that readers took the time to read and reply to other users' comments is a strong indication that these areas have great deliberative potential. This conclusion is reinforced by high levels of reflexivity, about $50 \%$ of the messages ${ }^{4}$, demonstrating that participants not only responded to messages, but also sought to present new arguments or to reflect on other posts.

As expected, justifications reached a high rate of $44,2 \%(39.6 \%$ of external justifications and $4,6 \%$ of internal justifications), though even higher rates were expected. It was believed that a discussion on an online newspaper site would have encouraged the users to post links, data, facts and external references to support arguments. However, it was notable that testimonials were few and far between (only 4.6\%). 
Surprisingly, the aggressive tone of the discussion was more pronounced than expected. The amount of insults, irony and even attempts to humiliate or belittle other users was high, exceeding $50 \%$ of the reviewed messages ${ }^{5}$. As advanced by Papacharissi (2004), it is not plausible to make a direct link between the level of aggression and low levels of deliberation. Users can be offensive but still submit new arguments, reflections and seek to advance the discussion. Nevertheless, this high index, together with the determination to "win" debates and discredit opponents, is rather worrisome.

The indicator of political stance proved to be particularly pertinent, with a rate of $50 \%$ of all messages. Contrary to expectations, it was possible to prove that the topics could not level out the users' ideological positions. It is clear, especially in discussions on the second topic, that there were a considerable number of readers who were against Lula's government (or his party, the PT, in general), just because it was deemed to be a government action. In the case of the first topic, although it was about a corruption scandal affecting the government's opposition party at the federal level, posts that were antagonistic towards Lula's government represented the majority. Even with regard to the third theme, the Human Rights Plan, the separation between the "situation" and the "opposition" was remarkable, especially given that representatives of the opposition believe the plan was linked to those who fought against the dictatorship.

Thus, it can be stated that theme and political positioning were the main predictors of certain indices. The second theme, which was the most controversial one, generated the highest volume of dialogue, reflexivity and user aggressiveness when compared to the first theme. This replicates the results found in Sampaio, Maia \& Marques (2011), where the most controversial issues also involved higher rates of deliberation and aggressiveness among participants.

Overall, the qualitative reading indicated that participants were more interested in winning the debate than reaching a common understanding. Furthermore, low persuasion rates demonstrate that participants did not show openness to review their positions. This result replicates findings in other studies on online deliberations in the wild (DAVIS, 2005; JANSSEN, KIES, 2005; SAMPAIO, MAIA, MARQUES, 2011 ; WILHELM, 2000).

Firstly, this result does not necessarily indicate an antidemocratic environment. Kelly and his team (2009) also found similar findings in their study of online forums made available by the American 
"Usenet". According to the results obtained in this study, research suggests that when there is clear division between two opposing groups, participants tend to respond more to the opponents that to allies. As such, participants who do not directly contribute to the debate tend to be ignored by those who play an active role in the discussion. Therefore, "what threatens democratic online, political discourse and invites the worst sort of extremity is not the presence of radical voices, but the absence of reasoned ones" (KELLY et al., 2009, p. 92).

Similarly, Lev-On and Manin (2009) argue that such discursive spaces are "Happy Accidents". After all, if many critics claim that the internet allows individuals with similar thoughts to gather and filter out contrary opinions (DAVIS, 2005; WILHELM, 2000), than "places" that allow the clash between very different perspectives, as the news comment tools are welcome.

Finally, the results of this study on deliberativeness show that, although the participants do not seek consensus with regard to opinions, they are interested in discussing and presenting their views, arguments and perspectives. Yet, it must be remembered that the study analyzed a weak public space (as regards empowerment) with a simple design geared only towards online discussion. These are factors that would tend to reduce the quality of the deliberation process ${ }^{6}$.

If cases of radical partisan views and/or examples of extremism demonstrate the pragmatic difficulty in pursuing mutual understanding, deliberative theory begins to offer normative answers in the form of meta-consensus (DRYZEK; NIEMEYER, 2006).

\section{CONCLUSION}

In addition to offering a discursive space for deliberation on the internet, the tool also offers three potentialities that merit some consideration. First, the "Folha de S. Paulo" and the "Folha.com" vehicles have great journalistic clout and credibility among Brazilians. Folha de S. Paulo's printed version is Brazil's largest newspaper with paid circulation?. The mere fact that these comments are posted in relation to news items gives them great visibility.

Secondly, there is great potential for enriching information regarding the news in question. As well as being able to read the message, readers can assess its impact (FIDALGO, 2004; LEV-ON, MANIN, 2009; NEWMAN, 2009). Regardless of whether the reader participates in the debate, they may come across new perspectives, information and 
statements that they otherwise would probably not have encountered simply through reading the original story.

Thirdly, participants gain (at least potentially) more understanding of why objectors adopt certain stances, through being exposed to divergent views. They also get to appreciate the extent to which the views of both groups are different (and perhaps even realize that the differences are not as significant as initially thought). This is consistent with the findings of Price et al. (2002), who found "a positive association between exposure to disagreement and respondents' ability to generate reasons why other people might disagree with them" (p. 107).

Future studies should focus less on controlled environments specifically designed to encourage deliberation and more on online deliberation in the wild. On one hand, it is important to know the rules and techniques for creating digital environments for good, qualified decisions. On the other hand, it should be remembered that many of the discursive tools available on the internet were not created to foster deliberation. Therefore, further studies are needed to consider the issue of aggression and the desire of participants simply to win debates rather than seeking a common understanding (or meta-consensus). Finally, the topic or issue under discussion - a question that is often overlooked should be taken more into account as a vital factor influencing online deliberation.

\section{$I_{\text {NOTES }}$}

1 http://www1.folha.uol.com.br/folha/brasil/ult96u692844. shtml. Retrieved July $13^{\text {th }} 2010$.

2 http://www1.folha.uol.com.br/folha/mundo/ult94u737126 shtml. Retrieved July $13^{\text {th }} 2010$.

3 In another study on tools to post comments (Sampaio, Maia \& Marques, 2011 ), the dialogue index was around $30 \%$.

4 One might compare this, for example, with the result of $20 \%$ found in Sampaio, Maia \& Marques (2011).

5 Again, as a parameter, the aggressive messages accounted for only $6 \%$ in Sampaio, Maia \& Marques (2011) and 11\% in Miola (2009). 
6 These two factors were the main indicators of certain low rates of deliberativeness in the study compiled by Sampaio, Maia $\&$ Marques (2011).

7 Data from the Checker Circulation (IVC) provided by the National Newspaper Association: http://www.anj.org.br/a-industria-jornalistica/ jornais-no-brasil/maiores-jornais-do-brasil. Retrieved June 22nd, 2009.

\section{REFERENCES}

BARROS FILHO, C.; MARTINO, L. M. S. O habitus na comunicação. São Paulo: Paulus, 2003. 246 p.

DAHLBERG, L. Net-Public Sphere Research: Beyond the "First Phase". The Public, v. 11 , n. 1, p. 27-44, 2004. Available at: http:// javnostthepublic.org/article/pdf/2004/1/2/. Accessed on: 20 ago. 2012.

DAVIS, R. Politics Online: Blogs, Chatrooms and Discussion Groups in American Democracy. Londres: Routledge, 2005.

DRYZEK, J. S., NIEMEYER, S. Reconciling Pluralism and Consensus as Political Ideals. American Journal of Political Science, n.50, v.3, p. 634-649, 2006.

FIDALGO, A. Sintaxe e Semântica das Notícias Online: Para um Jornalismo Assente em Base de Dados. In: LEMOS, André e outros. Mídia.br. Porto Alegre: Editora Sulina, 2004, p. 180-192.

FLEW, T.; WILSON, J. Journalism as social networking: The Australian youdecide project and the 2007 federal election. Journalism, v. 11, n. 2, p. 131-147, 2010.

FOLHA DE S. PAULO. História da Folha. In: Circulo Folha. Disponível em: http://www1.folha.uol.com.br/folha/circulo/historia_folha.htm Acesso em: 9 jul. 2010.

GANGADHARAN, S. P. Understanding Diversity in the Field of Online Deliberation. In: DAVIES, Todd; GANGADHARAM, Seeta Peña (Orgs.). Online Deliberation: Design, Research, and Practice. Stanford: CSLI Publications, 2009. p. 329-347.

GILLMOR, D. We the Media: Grassroots Journalism by the People, for the People. Sebastopol, CA: O'Reilly Media. 2004.

GOMES, M.; ANDRADE, I. H. Leitor-autor: análise dos comentários 
sobre matérias jornalísticas que tratam de exploração sexual cometida contra crianças e adolescentes. Revista Comunicação Midiática, v.5, n.1, 2010, p.8-27.

GRAHAM, T. Needles in a Haystack: a New Approach for Identifying and Assessing Political Talk in Nonpolitical Discussion Forums.

Javnost-The Public, v.15, n. 2, 2008, p.17-36.

HABERMAS, J. Between Facts and Norms: Contributions to a Discourse Theory of Law and Democracy. Cambridge, Massachusetts: The MIT Press, 1996. 673 p.

HAMLETT, P. Adapting the Internet to Citizen Deliberations: Lessons Learned. In: International Symposium on Technology and Society, 2, 2002, Raleigh, North Carolina, USA. Anais... 2002, p. $213-218$.

HERMIDA, A.; THURMAN, N. Comments please: How the British news media are struggling with user-generated content. In: International Symposium on Online

JANSSEN, D.; KIES, R. Online Forums and Deliberative Democracy. Acta Politica, n. 40, 2005, p. 317-335.

JENSEN, J. L. Public Spheres on the Internet: Anarchic or GovernmentSponsored - A Comparison. Scandinavian Political Studies, v. 26, n. 4, 2003, p. 349-374.

KELLY, J.; FISHER, D.; SMITH, M. Friends, Foes, and Fringe: Norms and Structure in Political Discussion Networks. In: DAVIES, Todd; GANGADHARAM, Seeta Peña (Orgs.). Online Deliberation: Design, Research, and Practice. Stanford: CSLI Publications, 2009, p. 83-94.

KIES, R. Promises and Limits of Web-deliberation. New York, NY, Palgrave Macmillan, 2010. 200 p.

KOHN, A.; NEIGER, M. To Talk and Talkback: Analyzing the Rhetoric of Talkbacks in Online Journalism. In: Israel Communication

Association Conference. Hebrew University, Jerusalem, 2006.

LEV-ON, A.; MANIN, B. Happy Accidents: Deliberation and Online Exposure to Opposing Views. In: DAVIES, Todd; GANGADHARAM, Seeta Peña (Orgs.). Online Deliberation: Design, Research, and Practice. Stanford: CSLI Publications, 2009. p. 105-122.

MANOSEVITCH, E.; WALKER, D. Reader Comments to Online Opinion Journalism: A Space of Public Deliberation. In: International Symposium on Online Journalism, 10, 2009, Austin. Anais... 2009, p. 1-30.

MARQUES, A. C. S. A deliberação online como uma das dimensões políticas da comunicação mediada por computador: reflexões 
teórico-metodológicas. In: Congresso Brasileiro de Ciências da Comunicação (Intercom), 33, 2010, Caxias do Sul. Anais... 2010.

MIGUEL, L. F.; BIROLI, F (Orgs.). Mídia, representação e democracia. São Paulo: Hucitec, 2010.

MIN, S. Online vs. face-to-face deliberation: Effects on civic engagement. Journal of Computer-Mediated Communication, v. 12, 2007, p.1369-1387.

MIOLA, E. A Deliberação Online em ambientes institucionais. Um Estudo do Fórum de Discussão do Portal da Câmara dos Deputados. Contemporânea, Salvador, v. 7, n. 2, 2009, p. 2-24.

MITCHELSTEIN, E.; BOCZKOWSKI, P. J. Online news consumption research: An assessment of past work and an agenda for the future. New Media \& Society, v. 12, n.7, 2010, p. 1085-1102.

MOUFFE, C. For an Agonistic Model of Democracy. In: MOUFFE, C. The Democratic Paradox. London: Verso, 2000, p.80-107.

NEBLO, M. A.; ESTERLING, K. M.; KENNEDY, R. P.; LAZER, D. M. J.; SOKHEY, A. E. Who wants to deliberate - and why? American Political Science Review, v. 104, n. 3, 2010, p. 1-18.

NEWMAN, N. The rise of social media and its impact on mainstream journalism. Working Papers. Oxford: Reuters Institute for the Study of Journalism, 2009, p. 1-55.

NOCI, J. D.; DOMINGO, D.; MASIP, P.; MICÓ, J. L.; RUIZ, C. Comments in News, Democracy Booster or Journalistic Nightmare: Assessing the Quality and Dynamics of Citizen Debates in Catalan Online Newspapers. In: International Symposium on Online Journalism, 11, 2010, Austin, Texas. Anais... 2010. p. 1-20.

PALACIOS, M. Positioning yet another idea under the glocalisation umbrella: Reader participation and audience communities as market strategies in globalised online journalism. Communicatio: South African Journal for Communication Theory and Research, v. 36, n. 2, 2010 , p. $276-287$.

PAPACHARISSI, Z. Democracy online: civility, politeness, and the democratic potential of online political discussion groups. New Media and Society, v. 6, n.2, 2004, p. 259-283.

PRICE, V.; CAPPELLA, J.; NIR, L. Does Disagreement Contribute to More Deliberative Opinion? Political Communication, n. 19, 2002, p. 95-112.

ROBINSON, S. Traditionalists vs. Convergers Textual Privilege, Boundary Work, and the Journalist-Audience Relationship in the Commenting Policies of Online News Sites. Convergence: The 
International Journal of Research into New Media Technologies, v. 16 , n. 1, 2010, p.125-143.

ROSENBERRY, J. Few papers use online techniques to improve public communication. Newspaper Research Journal, v. 26, n. 4, 2005, p. 61-73.

SAMPAIO, R. C.; BARROS, S. A. R. Deliberação no Jornalismo Online: um estudo dos comentários do Folha.com. Intexto, Porto Alegre: UFRGS, v. 2, n. 23, 2010, p. 183-202.

SAMPAIO, R. C; DANTAS, M.. Deliberação online em fóruns de discussão: Um estudo dos potenciais democráticos do Cidadão Repórter. Contracampo, Niterói, n. 22, p. 159-177, 2011.

SAMPAIO, R. C.; MAIA, R. C. M.; MARQUES, F. P. J. A.. Participation and Deliberation on the Internet: A case study on Digital Participatory Budgeting in Belo Horizonte. The Journal of Community Informatics, v. 7, p. 1-22, 2011.

SANDERS, L. Against Deliberation. Political Theory, v. 25, n. 3, 1997, p. 347-364.

SHAPIRO, I. Enough of Deliberation: Politics is about Interests and Power. In: MACEDO, S. (ed.). Deliberative Politics: Essays on Democracy and Disagreement. New York: Oxford University Press, 1999, p. 28-38.

WILHELM, A. Democracy in the digital age: challenges to political life in cyberspace. New York: Routledge, 2000.

WRIGHT, S.; STREET, J. 2007. Democracy, deliberation and design: the case of online discussion forums. New Media Society, Londres, v. 9, p. 849-869.

YOUNG, I. Communication and the Other: Beyond Deliberative Democracy. In: BENHABIB, S. (Org.). Democracy and Difference. Princeton: Princeton University Press, 1996. 